\title{
Zika Vírus, Expertises e Moralidades - A ADPF 442 e as Controvérsias em Torno da Descriminalização do Aborto
}

Zika Virus, Experts and Moralities - ADPF 442 and the Controversies

Surrounding Decriminalization of Abortion

\author{
Jonatan Sacramento ${ }^{1}$ \\ Maria Conceição da Costa ${ }^{1}$
}

${ }^{1}$ Universidade Estadual de Campinas, Campinas, SP, Brasil 


\section{Resumo}

O objetivo deste artigo é analisar as controvérsias em torno da descriminalização do aborto na audiência pública da Arguição de Descumprimento de Preceito Fundamental (ADPF) 442, no Supremo Tribunal Federal, em agosto de 2018, que teve lugar a partir da epidemia de Zika Vírus e microcefalia no Brasil em 2015. A partir da análise dos argumentos apresentados pelos defensores e opositores da matéria em questão, nosso objetivo é analisar como tais argumentos foram construídos pelos atores e quais as estratégias/motivações técnicas, científicas, políticas, morais, legais, etc. foram utilizadas para sustentá-los. Parte-se do pressuposto de que o gênero está construindo tais argumentos, como tem sustentado a literatura sobre a ideia de coprodução e duplo fazer.

Palavras-chave: Zika Vírus. Controvérsia Científica. ADPF 442. Gênero e Ciência. Coprodução.

\section{Abstract}

The aim of this article is to analyze the controversies surrounding the decriminalization of abortion at the public hearing of the "Arguição de Descumprimento de Preceito Fundamental" (ADPF) 442 at the Federal Supreme Court in August 2018, which took place following the Zika Virus and microcephaly epidemic which began in Brazil in 2015. From the analysis of the arguments presented by the defenders and opponents of the subject in question, our objective is to analyze how these arguments were constructed by the actors and which strategies, technical, scientific, political, moral, legal, etc., were used to support them. It is assumed that gender is constructing such arguments, as the literature on the idea of co-production and double doing has supported.

Keywords: Zika Virus. Scientific Controversy. ADPF 442. Gender and Science. CoProduction. 


\section{Introdução}

— $m$ abril de 2015, pesquisadores brasileiros confirmaram a circulação de um novo arbovírus no país. Naquela ocasião, confirmaram também a hipótese de ligação entre o Zika Vírus e os casos de microcefalia (Síndrome Congênita do Zika) que vinham acontecendo, principalmente, na Região Nordeste do país (DINIZ, 2016). Desde a descoberta da doença e da confirmação pelo Ministério da Saúde da ligação causal entre doença e microcefalia, o cenário em torno do Zika Vírus esteve envolto em controvérsias ${ }^{1}$. No interior desse cenário, este artigo tem como objetivo discutir a controvérsia instaurada no Supremo Tribunal Federal (STF) em decorrência da Arguição de Descumprimento de Preceito Fundamental (ADPF) que demandava a descriminalização da interrupção voluntária da gravidez nos casos em que o feto fosse diagnosticado com microcefalia (posteriormente a matéria passou a englobar a interrupção em todos os casos até a décima segunda semana de gravidez). O objetivo aqui será o de colocar sob escrutínio sociológico os argumentos apresentados pelos expertos na defesa de seus pontos de vista sobre a possibilidade ou não do Supremo Tribunal acatar a pauta em questão.

O trabalho está dividido em quatro partes. Na primeira, fazse uma pequena discussão sobre os principais conceitos e ideias apresentadas no texto, a saber, o idioma da coprodução, a ideia de duplo fazer, a de controvérsia científica e a de economia moral da ciência. Na segunda parte, é descrito o processo de julgamento da ADPF 442 e são apresentadas também cinco cenas etnográficas, a fim de apontar as principais controvérsias e os embates políticos presentes no debate. Na terceira parte, traremos uma discussão sobre os principais pontos 
levantados nas cenas narradas e, por fim, a quarta parte é dedicada aos apontamentos finais.

\subsection{Alguns Conceitos Importantes - Coprodução, Controvérsias, Duplo Fazer e Economia Moral}

Para a compreensão das discussões que serão levantadas no artigo, é importante entender que a relação entre a produção científica e intelectual de uma determinada área e a produção de discursos políticos sobre determinadas demandas estão inter-relacionadas com o contexto social no qual são produzidas. Ao mesmo tempo, é esse mesmo contexto que permite a emergência dos diversos discursos políticos e científicos que, de alguma forma, tentam conformar e/ou criar outros contornos à dinâmica social. A isso Sheila Jasanoff $(2004 ; 2015)$ tem chamado de coprodução, um idioma, um caminho para interpretar o mundo para além das dicotomias entre natureza e cultura, agência e estrutura, indivíduo e sociedade.

O idioma da coprodução compreende a produção conjunta entre as ordens sociais e naturais da sociedade, além da compreensão de que os modos como conhecemos e representamos o mundo são inseparáveis dos modos como escolhemos vivê-lo. Ou seja, há sempre um suporte social apropriado para todo conhecimento que é produzido. Essa corporificação, no mundo social, do conhecimento e de suas tecnologias, é capaz de criar imaginários sociotécnicos (JASANOFF, 2015) que se refletem na concepção e na realização de projetos científicos, intelectuais e tecnológicos específicos a cada contexto social. Nesse sentido, os imaginários sociotécnicos também operaram na lógica de coprodução ao serem resultados e, ao mesmo tempo, produzirem as relações e os processos nos quais estão inseridos.

No âmbito das discussões levantadas neste artigo, o idioma da coprodução nos ajuda a pensar as controvérsias científicas e a disputa pública em torno dos direitos sexuais e reprodutivos, em especial, do caso da descriminalização do aborto quando do feto ser portador de microcefalia e/ou até a décima segunda semana de gravidez. Como veremos mais adiante, quando a discussão toma lugar no Supremo 
Tribunal Federal, instauram-se algumas controvérsias científicas que mobilizam argumentos e expertises de diversos campos de conhecimento ${ }^{2}$.

Uma controvérsia científica é definida como um dissenso e/ou uma disputa pública no interior de um determinado campo intelectual, entre expertos ou não, sobre uma determinada questão envolvendo esse campo. Menos que uma inconsistência no interior da disciplina, a controvérsia é elemento básico constitutivo na conformação do conhecimento científico e que permite com que a ciência se mantenha em processo de construções contínuas. O fim de uma controvérsia pode se dar de duas maneiras: a resolução do dissenso, mas também, e não pouco incomum, por meio do enclausuramento de tais tensões em "caixas pretas", ou ainda, pelo abandono de tal querela (GIERE, 1989; MCMULLIN, 1989; NELKIN, 1989; CLARKE, 1990).

Para a compreensão das dinâmicas de funcionamento da controvérsia científica, se faz necessário considerar os vários pontos de vista que compõe o debate, levando em consideração os inúmeros "mundos sociais" que se interseccionam nesse processo (CLARKE, 1990). É necessário também, afirma Nelkin (1975), compreender o papel dos expertos no interior dessa controvérsia. Para a autora, os expertos desempenhariam um papel ambivalente na dinâmica política das controvérsias, sendo, ao mesmo tempo, indispensáveis para a resolução da questão e suspeitos, por serem acusados de representarem determinados interesses - a despeito das tentativas de cientistas de se livrarem de toda e qualquer influência e/ou ideologia (GIERYN, 1983).

No entanto, como destaca Nelkin (1975) ${ }^{3}$, pode-se perceber um processo de politização da expertise, tanto quando cientistas assumem determinadas posições, a depender da agenda política do contexto no qual estão localizados, quanto quando o próprio conhecimento científico é manejado pelos atores da controvérsia de forma a legitimarem suas posições - como veremos neste texto. Nesse sentido, o que se propõe neste artigo é que a própria controvérsia seja entendida na lógica do idioma de coprodução, ou seja, na lógica de produção simultânea e constitutiva entre a ciência, o Estado, a política e o mundo social.

No caso das controvérsias instauradas pela ADPF 442, no entanto, outro elemento deve ser considerado para a feitura dessa análise: o gênero. Como mostramos em outra oportunidade (SACRAMENTO; 
COSTA, 2018), as respostas em torno da epidemia do Zika Vírus e da Síndrome Congênita do Zika têm sido marcadas pelo gênero, quer dizer, pelos significados socialmente construídos sobre masculinidades e feminilidades, sobre maneiras imaginadas de ser homem, mulher e, notadamente, sobre os significados de ser mãe. Assim, vale a pena traçarmos algumas considerações sobre o gênero, os processos de governança pública e as dinâmicas de produção do conhecimento científico.

Os processos de governança pública, ou de fazer Estado, estão marcados não apenas por categorias oficiais da burocracia estatal produzidas no cotidiano, como também pela materialização das categorias de diferenciação elaboradas pelo próprio Estado (mas não apenas). Assim, os modos de regulação e enquadramento gerados pelo Estado por meio da produção de categorias oficiais também estão perpassados por significados de gênero (e raça, etnia, classe, etc.) que são, ao mesmo tempo, produzidos pelo Estado e produtores deles. Nesse entendimento de que gênero e Estado são categorias processuais, ou seja, "[uma] coprodução simultaneamente dramática e cotidiana [...]" (VIANNA; LOWENKRON, 2017, p. 6, a análise do duplo fazer entre gênero e Estado, e acrescentamos, entre gênero e ciência, nos permite perceber as relações de coprodução entre ciência e sociedade em suas múltiplas faces.

Assim, compreender o Estado como uma trama de sentidos, feitas e refeitas cotidianamente por meio das dinâmicas de gênero, e entender o gênero como produto dessas mesmas tramas estatais, nos permite olhar para processos como a ADPF 442 de forma a entender como estão relacionados a construção de um problema social, científico, jurídico e suas respostas no interior dos processos sociais mais amplos, perpassados por categorias outras que não apenas as do Direito, da Saúde Pública e da burocracia estatal, mas também por gênero e moralidades.

A ciência, diz Lorraine Daston, possui valores próprios, mas que não estão em dissonância com os valores da sociedade na qual está inserida. Nesse sentido, a economia moral da ciência, entendida como uma rede afetos que se sustentam e funcionam em relações recíprocas 
(DASTON, 1995), opera como um estado mental coletivo partilhado pela comunidade de cientistas ${ }^{4}$ e que se constitui como parte integrante do fazer científico e do modo de operar deste (como no exame e na demonstração das provas científicas). Economia é aqui entendida pela autora como um sistema organizado que apresenta certa regularidade. Moral, por sua vez, seria um conjunto de imperativos comportamentais e normativos.

Menos que aquilo que anima a atividade científica, essa economia moral seria parte constitutiva do processo de produção da ciência, assim como também o são os métodos, os protocolos, os objetos e os próprios dados científicos etc. E menos que um falseamento da realidade científica, continua a autora, os valores que moralizam a ciência seriam parte constitutivas da prática científica em um determinado momento histórico e contexto social. Assim, tal economia seria ela também a própria ciência.

No caso das pesquisas no campo sexual e reprodutivo nos Estados Unidos, Adele Clarke (1990) afirma que as políticas científicas se confrontam com as políticas morais. Nesse sentido, para angariar fundos e defender os interesses científicos da área, os cientistas americanos tiveram de erguer uma voz de autoridade e saber falar tanto para os leigos quanto para o público de especialistas. Outra estratégia foi a de tornar pública menos as controvérsias do campo e focar mais nas relações entre as pesquisas científicas e seus impactos na resolução de alguns problemas sociais.

Seguindo as reflexões de Clarke, que objetiva mostrar como as controvérsias científicas são parte constitutiva do processo de produção científica e, também, como os fatores externos, como as moralidades e os posicionamentos políticos constituem os campos de saber, este artigo se propõe a pensar a controvérsia instalada quando da epidemia de Zika Vírus e a microcefalia a ela associada trouxeram à tona, novamente, a discussão sobre a possibilidade de alargamento das oportunidades legais de interrupção voluntária da gravidez (aborto). 


\section{A ADPF 442 em Questão}

No contexto da epidemia de Zika Vírus, a ONG Anis - Instituto de Bioética, conhecida por sua atuação em defesa dos direitos sexuais e reprodutivos, com auxílio da Wellcome Trust, desenvolveu em $2016^{5}$ (5) uma pesquisa que fez um levantamento da realidade social das mulheres do nordeste brasileiro, afetadas pela epidemia de Zika, e de seus filhos, afetados pela Síndrome Congênita do Zika. Junto ao Partido Socialismo e Liberdade (PSOL), partido político que flerta com a pauta feminista, conseguiram levar ao Supremo Tribunal Federal o pedido de Arguição de Descumprimento de Preceito Fundamental (ADPF) alegando que a conjunção Zika Vírus e Síndrome Congênita do Zika criava uma situação de desigualdade jurídica para as mulheres na medida em que o acesso à interrupção voluntária da gravidez lhes era negado.

À época da realização da pesquisa, momento do epicentro da epidemia, as autoridades de saúde brasileiras se recusavam discutir qualquer possibilidade de ampliação dos direitos sexuais e reprodutivos ou mesmo de políticas coletivas de prevenção à gravidez. O contrário, as orientações disponibilizadas pelo Ministério se voltaram para a atuação individual das mulheres que, dado o cenário de epidemia, deveriam postergar a decisão pela gravidez e/ou adotarem comportamentos contraceptivos individuais (SACRAMENTO; COSTA, 2018).

A ADPF 442 foi solicitada pelo PSOL, com pedido de medida cautelar, em 6 de março de 2017. A partir de um documento de 62 páginas em que o requerente solicitava que a Suprema Corte declarasse a não recepção parcial dos artigos 124 e 126 do Código Penal brasileiro, Lei n. 2.848, de 1940, que dispõe sobre a criminalização do aborto, pedia que se fosse excluído do entendimento dessa lei a "interrupção da gestação induzida e voluntária" (PSOL, 2017, p. 61) até a 12a semana de gravidez. No documento, além de lançar mão de uma reconstituição histórica das diversas experiências envolvendo a descriminalização do aborto nas supremas cortes de diversos países, como Alemanha, Estados Unidos, México, entre outros, o partido ainda discorria sobre as desigualdades advindas do processo de criminalização da prática e que incorreria 
na discriminação das mulheres, negando-lhes uma equiparação aos homens em termos de direitos civis, além do impedimento ao acesso de uma cidadania integral e aos direitos sexuais e reprodutivos.

Uma Arguição de Descumprimento de Preceito Fundamental é um instrumento jurídico que tem por objetivo promover ou reparar um preceito constitucional fundamental que, resultante de ato do poder público, venha sendo considerado omisso - Lei n. 9.882/99 (BRASIL, 1999). Conforme prevê a legislação que a institui, a petição deve conter a indicação do preceito que se considera violado, a prova de violação dele e, quando for o caso, a comprovação da existência de uma controvérsia judicial "relevante", palavras da lei, sobre a aplicação do preceito. No Supremo Tribunal Federal, a relatoria da ADPF ficou a cargo da Ministra Rosa Weber.

\subsection{Etnografando uma Audiência (6)}

Na manhã do dia 3 de agosto de 2018, a Ministra e presidente de Supremo Tribunal Federal, Carmen Lúcia Soares, abriu o primeiro dia da sessão de audiência da ADPF 442, que versava sobre a descriminalização da interrupção voluntária da gravidez (o aborto) até a $12^{\mathrm{a}}$ semana de gestação ${ }^{6}$. Compondo a mesa, estavam também a ministra Rosa Weber, relatora do processo, o ministro Luis Roberto Barroso, o vice-Procurador da República, doutor Luciano Mariz Maia, e a Advogada Geral da União, doutora Grace Mendonça. Além das autoridades da mesa, a sessão era composta também dos representantes das 53 entidades científicas, civis, religiosas e governamentais, nacionais e internacionais, chamados a participarem do debate que daria subsídios para a relatora do processo construir o relatório que guiaria a discussão dos ministros quando do julgamento da matéria em momento posterior ${ }^{7,8}$.

A audiência aconteceu durante dois dias e foi dividida em quatro sessões cujo tempo foi dedicado exclusivamente para a exposição dos especialistas a respeito de seu ponto de vista (favorável ou contrário) em relação à matéria em questão. Neste artigo, o foco será dado a cinco cenas etnográficas que sintetizam, ao nosso ver, as principais controvérsias levantadas na audiência. Menos que tentar resumir a posição dos diversos atores e expertos ou de escolher uma exposição que 
melhor os representasse, nosso objetivo é reconstruir os argumentos que foram apresentados pelos expositores que se posicionavam contrários e favoráveis ao acolhimento da pauta em questão, dando ênfase aos diferentes elementos que sustentavam as arguições e as controvérsias ali levantadas.

\subsubsection{Cena I - Um Problema de Saúde Pública?}

O primeiro dos expositores a se apresentar foi o Ministério da Saúde, representado pelas médicas Mônica de Almeida Neri e Maria de Fátima, que trouxeram os dados oficiais do Datasus sobre a situação do aborto no Brasil, construindo-o como um problema de saúde pública, principalmente em relação às mortes em decorrência daqueles procedimentos considerados inseguros e dos determinantes sociais em saúde que poderiam ou não agravar o problema. A partir da exposição das duas médicas, os especialistas que se apresentaram depois, de uma forma ou de outra, fizeram referência aos dados oferecidos pelo Ministério para alegarem que o aborto seria uma questão de saúde pública e que, por isso, e em detrimento da garantia da saúde da mulher gestante, ele deveria ser descriminalizado como forma de diminuir e/ou eliminar as mortes em decorrência do abortamento clandestino e inseguro no país. Seguindo esse argumento estavam a Federação Brasileira das Associações de Ginecologia e Obstetrícia, a Academia Nacional de Medicina, o Instituto Paraibano de Pesquisa, o Centro de Pesquisa em Saúde Reprodutiva de Campinas e o Conselho Federal de Psicologia.

A primeira exposição contrária à aceitação da pauta pelo STF, e que também tentava desconstruí-la enquanto um problema de saúde pública, foi apresentada pelo Instituto Liberal de São Paulo, representado pelo médico obstetra e professor universitário, Raphael Câmara. Raphael alegou que sua exposição iria no sentido de esclarecer as "mentiras" em torno da questão da descriminalização do aborto, notadamente a de que alguns marcadores sociais como raça, classe e distribuição geográfica pesariam na conformação do acesso a esse tipo de procedimento, além de desconstruir a tese de que o aborto seria uma questão de saúde pública. Antes, para o obstetra, não existiria 
uma epidemia de abortos inseguros no país e os dados produzidos sobre essa questão seriam inflados, não confiáveis e financiados por aquelas instituições claramente "pró-aborto". Os estudos sobre o tema, por sua vez, seriam publicados apenas em revistas de baixo impacto científico, não devendo ser levados em consideração para mensurar a possível gravidade do problema.

Segundo o expositor, o problema de saúde pública existiria se a pauta fosse acatada e o aborto fosse descriminalizado, já que a prática, por ser considerada pelo expositor como menos segura que a técnica de cesariana, seria um procedimento arriscado e que oneraria os cofres públicos.

A fala do obstetra Raphael Câmara e sua argumentação sobre a confiabilidade dos dados sobre os casos de aborto no Brasil não ficou sem resposta. Ainda que não falando diretamente para ele, a antropóloga Debora Diniz, que falou como representante da ONG Anis - Instituto de Bioética, pautou sua exposição no que ela chamou de "ciência confiável", ou seja, aquela ciência baseada na "empiria" e que poderia oferecer meios para que a suprema corte pudesse pautar sua decisão sobre a matéria em questão. Para Débora, os dados não falariam por si só, mas antes, deveriam ser questionados sobre sua origem, quem os coletou e como foram disseminados, no sentido de torná-los evidências (científicas) "confiáveis" que pudessem pautar decisões públicas como aquela.

\subsubsection{Cena II - Controvérsias Científicas}

A ideia de ciência confiável e de que a ciência, notadamente a biologia e suas subdisciplinas, dariam respostas a pauta em questão foi mobilizada não apenas pela representante da ONG Anis. Ao contrário, e principalmente por parte dos expertos contrários à ADPF, o recurso aos argumentos científicos se fizeram presentes, não mais questionando a confiabilidade dos dados e a pertinência (ou não) de se tratar de um problema de saúde pública, mas ao colocar em xeque a ideia de início da vida e quais as repercussões da descriminalização do aborto para essa questão. 
Nessa direção, expositores como a representante do Conselho Nacional do Laicato do Brasil, a médica Silvia Maria de Vasconcelos, defendeu a posição de sua instituição alegando, enquanto uma especialista, que a vida começava no momento da concepção, argumento que foi levantado pelos expertos e também pelos juristas, representantes da Convenção Geral das Assembleias de Deus, da Federação Espírita Brasileira, da União dos Juristas Católicos de São Paulo e da Associação dos Juristas Evangélicos.

Nessa lógica argumentativa, do encontro do zigoto com o óvulo nasceria o embrião e a partir dali já existiria uma nova vida. A descriminalização do aborto, por sua vez, seria então um crime de assassinato.

Essa mesma retórica de matar um sujeito de direito foi acionada pelo representante da Frente Parlamentar em Defesa da Vida, o Senador Magno Malta (Partido da República - ES), ao alegar que os embriologistas afirmavam cientificamente que a vida começaria no momento da concepção. Nesse sentido, ao se posicionar favorável a ADPF, a Suprema Corte brasileira estaria se posicionando favoravelmente ao assassinato de sujeitos de direito'.

Essa ideia de início da vida desde a concepção foi o tema da tese apresentada pela bióloga e presidente da Sociedade Brasileira para o Progresso da Ciência (SBPC), Helena Nader ${ }^{10}$. Segundo a expositora, não haveria consenso científico a respeito do início da vida, mas antes, critérios de vida celular, mas que não seriam aplicados ao feto. A título de ilustrar seu argumento a expositora afirmou que desde 1981 a Academia Nacional de Medicina dos EUA afirma que a ciência não seria capaz de responder quando a vida se inicia, dado que cada campo disciplinar no interior da biologia usaria de critérios distintos para determinar o momento. Assim, continuou, a ideia da vida desde a concepção não poderia ser sustentada com argumentos científicos, apenas morais e filosóficos - "é preciso que fique claro", arrematou, "se o Brasil decidir continuar criminalizando as cidadãs brasileiras não poderá usar a ciência sobre o início da vida humana como pretexto". 


\subsubsection{Cena III - Vida e Eugenia}

Se a exposição da representante da Sociedade Brasileira para o Progresso da Ciência não finalizou a controvérsia em torno da questão do início da vida, cujo argumento ainda seria mobilizado por outros expositores contrários a pauta da ADPF naquela audiência, ele ao menos serviu para ascender um novo ânimo ao debate. O mesmo aconteceu quando da exposição do Instituto Baresi de doenças raras e do Movimento Nacional da Cidadania pela Vida - Brasil sem aborto, que trouxeram à tona a discussão sobre a representatividade e as possibilidades de se viver.

A exposição do Instituto Baresi de doenças raras, feita pela antropóloga Adriana Dias, foi a primeira exposição a suscitar na plateia uma reação em massa. Adriana falava como uma pessoa com deficiência e doenças raras e em nome de outros como ela. Para a expositora, o direito ao aborto não se contradizia com o direito das pessoas com deficiência. Ao contrário, a criminalização da prática só acentuaria os problemas de saúde pública causados pelas frágeis políticas de saúde reprodutiva para mulheres com deficiência. Além disso, ao fazer referência aos argumentos de uso eugênico do aborto, defendidos por aqueles que são favoráveis à continuidade da criminalização, a antropóloga disse que tais argumentos não teriam razoabilidade sociológica, já que a decisão individual da mulher sobre sua gravidez e seu aborto não seria uma decisão eugênica, antes "são decisões pessoais de mulheres". "O discurso de que a descriminalização pode implicar uma eugenia é uma usurpação da experiência das pessoas com deficiência para responsabilizar mulheres e meninas pela negligência do Estado na proteção dos nossos direitos", arrematou, sendo ovacionada de pé pela plateia.

Após o momento de euforia na audiência, foi a vez da doutora Lenise Aparecida Garcia falar em nome do Movimento Nacional da Cidadania pela Vida - Brasil sem aborto. "Eu achei muito interessante esse princípio 'nada sobre nós sem nós"', em referência à fala da antropóloga Adriana Dias, "mas aqui nós temos um problema, porque o mais interessado nessa conversa não pode falar, então eu preciso estar aqui para falar por ele", começa a expositora, enquanto segura com a mão direita levantada 
a miniatura de um feto. Segundo ela, para o feto não existiria aborto seguro. Ele sempre morreria.

O posicionamento contrário à $\mathrm{ADPF}$ sustentado pela expositora do Movimento Nacional da Cidadania pela Vida esteve pautado na premissa pasteuriana da não existência de geração espontânea. Assim, continuava Lenise, a relação entre paternidade, maternidade e filiação se estabeleceria no momento da fecundação. Desse modo, o pedido de descriminalização do aborto até a $12^{\mathrm{a}}$ semana de gravidez não deveria ser acatado, pois a vida teria início já na concepção.

\subsubsection{Cena IV - Dos Argumentos e dos Atores Religiosos}

Por parte dos expertos religiosos, como a Convenção Geral das Assembleias de Deus, a Federação Espírita Brasileira, a União dos Juristas Católicos de São Paulo e a Associação dos Juristas Evangélicos, as argumentações contrárias ao acolhimento da APDF pela Suprema Corte giraram em torno da ideia do início da vida no momento da concepção e que, nesse sentido, a vida deveria ser defendida pela legislação nacional. A Confederação Israelita do Brasil e a Federação das Associações Mulçumanas do Brasil, que se posicionaram favoráveis à ADPF, o fizeram com base nos preceitos das tradições judaicas e mulçumanas quanto a ideia de início da vida e de outros valores religiosos que defendiam a guarda da dignidade de seus fiéis.

No entanto, fora os judeus e mulçumanos, os representantes das religiões cristãs não usaram de argumentos religiosos ou de argumentos bíblicos para defenderem suas posições. Ao contrário, toda a argumentação desses atores foi construída sobre (uma) a premissa científica do início da vida quando da fecundação - tal como entende a embriologia. O recurso aos argumentos religiosos ficou à cargo de duas mulheres, a representante do grupo Católicas Pelo Direito de Decidir, a socióloga Maria José do Rosado Nunes, e a representante do Instituto de Estudos da Religião, a advogada e também pastora luterana Lusmarina Campos Garcia, que em suas falas fizeram questão de ressaltar que falavam em nome/usando de argumentos teológicos na construção de seus argumentos favoráveis à pauta. 
A exposição de Lusmarina afirmava que sua posição não colocaria em oposição fé e a descriminalização do aborto. Ao contrário, a defesa dessa tese se daria porque os argumentos contrários à descriminalização estavam pautados numa retórica religiosa que estaria atuando via poder político - ou judicial. Nesse mesmo sentido a exposição da socióloga Maria José do Rosado Nunes dizia não esconder o seu lugar de fala, enquanto mulher católica e feminista, ao contrário daqueles que ali estavam e que, segundo ela, usariam de argumentos científicos e jurídicos para justificarem sua fé e seus argumentos. A socióloga ressaltou que a legalização do aborto responderia uma questão de justiça social e racial, assim como seria uma questão de democracia, pois garantiria às mulheres que essas pudessem controlar sua capacidade de fazer uma nova vida. Para Maria José, seria dever ético da sociedade reconhecer as mulheres enquanto sujeitos plenos e capazes de decidir e, dessa forma, a pauta deveria ser acatada pela Suprema Corte.

\subsubsection{Cena V - Controvérsias Jurídicas}

Em meio às querelas científicas e morais sobre a corte acatar ou não a pauta da descriminalização do aborto, houve aqueles que, a despeito do tipo de instituição que representavam (se sociedade civil, científica ou órgãos de governo), optaram por se posicionar diante da questão desde uma perspectiva jurídica, a saber, a legitimidade jurídica do Supremo Tribunal Federal em legislar sobre uma questão como aquela.

Nesse sentido, a advogada e professora universitária Janaína Paschoal falou em nome da Universidade de São Paulo. No entanto, começou sua fala dizendo que sua posição seria diferente daquela que defende sua instituição. Segundo ela, a ADPF apresentada pelo PSOL trataria de dois artigos do Código Penal e que, por isso, deveriam ser tratadas como coisas distintas. Para a expositora, sua preocupação seria que o benefício da supressão do artigo 124 do mesmo código, que legisla sobre aquelas mulheres que autoprovocam o aborto, poderia tirar o ônus daqueles que, à época, estavam sendo investigados pelo artigo 126, que trata daqueles que provocam o aborto ainda que com o consentimento da gestante. 
A Conferência Nacional dos Bispos do Brasil (CNBB), por sua vez, representada pelo Padre José Eduardo de Oliveira, alegou que a ADPF seria ilegal, pois a petição inicial não cumpriria as normas exigidas por lei para a constituição de uma Ação (Lei n. 9.882/99), ao não apresentar uma controvérsia no âmbito do direito. Ao contrário, a Suprema Corte estaria fazendo "ativismo", ao legislar positivamente e usurpar o papel de outro poder.

Nessa mesma direção foi a fala do representante da Convenção Geral das Assembleias de Deus, Douglas Roberto de Almeida, que afirmava que caberia ao Congresso Nacional, e não ao STF, legislar sobre aquela pauta, e a Procuradoria Estadual do Sergipe, representada pelo advogado José Paulo Leão Veloso Silva, que afirmava que, por falta de representatividade democrática, a despeito da capacidade técnica, o STF não teria legitimidade para tomar qualquer decisão na matéria em questão.

\section{$3 \mathrm{Da}(\mathrm{s})$ Natureza(s) do Problema e de suas Controvérsias}

A controvérsia inicial instaurada quando do pedido da Arguição de Descumprimento de Preceito Fundamental e sua posterior audiência pelo Supremo Tribunal Federal foi a da possibilidade ou não da descriminalização do aborto nas 12 primeiras semanas de gravidez. O recurso a uma audiência com a participação da sociedade civil, na forma de expertos e interessados pelo tema, no entanto, trouxe à tona outros conflitos que, a princípio, não estavam previstos quando do pedido incialmente feito pelos proponentes. O surgimento de novos questionamentos no campo jurídico e no campo moral, a saber, a legitimidade ou não do STF legislar (positivamente) sobre o tema, o embate entre direitos das mulheres e direito do feto/à vida, e o da natureza do problema como sendo de saúde pública, jurídica ou moral, para além da pauta principal, são outros enfrentamentos que a Suprema Corte e o público da audiência tiveram de manobrar na tentativa de uma resolução do problema em questão.

Se, a princípio, o tema da descriminalização do aborto pode ser pensando como um problema de saúde pública, como coloca a literatura da área (BERQUÓ, 2003) e a fala de uma parte dos expositores 
favoráveis a ADPF 442, ela também foi construída como um falso problema por parte também de profissionais de saúde - como na fala do obstetra Raphael Câmara que, mesmo sem negar totalmente o caráter de problema de saúde, construiu sua argumentação pautado na ideia de que a descriminalização ou aumentariam os problemas e gastos do serviço público de saúde, ou seria uma solução errada para um problema que deveria ser enfrentado de outro modo - a saber, com educação sexual, políticas contraceptivas e até a flexibilização das leis de adoção.

Essas alternativas à descriminalização não estariam em total desacordo com a pauta proposta pelos favoráveis da ADPF e com a própria ADPF em si. Políticas sexuais e reprodutivas, que incluem estratégias de planejamento familiar, educação sexual com foco em prevenção de doenças e maior integração das políticas de saúde no âmbito dos cuidados básicos à saúde da mulher e da criança, também são soluções apontadas pelos favoráveis a descriminalização como ações que tem de andar junto com a possibilidade do aborto. No entanto, o que diferencia a tônica dos dois discursos no tocante a esse ponto parece ser um argumento de outra ordem. A fala da sociológica Maria José Rosado Nunes, representante do grupo Católicas Pelo Direito de Decidir, pode ser um elucidativo dessa questão. Ao afirmar estar falando como uma mulher católica e feminista e deixar claro sua posição dentro do campo da disputa, Maria José se colocou em relação à pauta como pessoa interessada, afetada por seus interesses pessoais e políticos e, segundo ela, agindo de maneira oposta ao dos muitos expositores contrários a ADPF, que usariam de argumentos jurídicos e legais para esconderem suas reais motivações - morais e políticas.

Que a ciência e o direito não estão isentos da influência e da política e das moralidades não é algo novo para as Ciências Sociais ou para a Antropologia (SHAPIN; SCHAFFER, 1985; JASANOFF, 1987, 2003; 2004; CORREA, 1983; LUGONES, 2017). Nesse sentido, a fala dos que se posicionaram a favor da ADPF também estava marcada por esses dois elementos. No entanto, o que diferenciava os defensores do opositores é que os favoráveis ou deixavam claro estarem falando em nome ou em defesa de grupos minoritários (como as mulheres 
pobres, negras, indígenas ou, até, as mulheres em geral, um minoria quando comparado ao que elas chamaram de sociedade com valores "patriarcais"), ou então apoiavam suas falas naquilo que Helga Nowotny (2003) tem chamado de conhecimento socialmente robusto (numa tradução nossa), ou seja, aquele conhecimento baseado em evidências científicas, produzidas por uma gama de atores e em múltiplos contextos sociais e que se modifica e se refaz em constante relação com a sociedade no qual está inserido. Robustez, continua a autora, deve ser entendido como um processo, algo relacional, e não um produto em si.

É nesse sentido que, menos que deslegitimar os argumentos de cunho jurídico apresentados pelos expositores contrários e favoráveis a ADPF (outra controvérsia científica que se instalou no processo analisado), já que esses também parecem apresentar solidez dentro do campo de especialistas, deve-se tomá-los como parte integrante do próprio campo. Menos que uma anomalia, a controvérsia jurídica sobre a possibilidade do STF acatar ou não a ADPF, sob pena de estar legislando positivamente, parece integrar a própria dinâmica da produção de conhecimento no campo do Direito. No entanto, vale ressaltar também que tal controvérsia apenas foi levantada por aqueles que se posicionaram contrários à matéria de que se trata a ADPF 442, postura que, inclusive, foi defendida pelos que se posicionam favoráveis, alegando que seria o papel da Suprema Corte resolver controvérsias em torno da interpretação de leis no Brasil. Novamente, pode-se perguntar se os que alegavam inconsistência estariam motivados por interesses outros que não apenas os técnico-científicos.

Nesse mesmo sentido poderia ser pensada a controvérsia apresentada pelos opositores da ADPF sobre o direito das mulheres versus o direito do feto, ou o direito à vida. Nessa lógica argumentativa há duas proposições que se desdobram. A primeira seria a de que a vida tem seu início com a fecundação do óvulo pelo espermatozoide, fato questionado pelos próprios cientistas presentes na audiência. A segunda, que se baseia na primeira, mas não depende dela, é a de que o feto é, de fato, um sujeito de direito e, por isso, a descriminalização do aborto significaria a autorização ou não punição para a morte do feto. Quer dizer, se desdobra para o âmbito jurídico uma controvérsia 
que põe em confronto direto sujeitos de direito, mas que depende da validade da premissa biológica de que a vida começaria na concepção - outra controvérsia por si só.

Por sua vez, dessa argumentação surge uma outra indagação que é a de saber se a descriminalização do aborto seria um problema de saúde pública, de ordem jurídica ou uma questão de ordem moral. A controvérsia que se instala nessa seara se dá por meio de um deslocamento por parte de especialistas (mas não apenas) que, mesmo não atuando na área da saúde, afirmavam que o tema se tratava de um problema de ordem jurídica, a despeito de quaisquer evidências científicas que os profissionais da saúde tenham sobre a temática. Quer dizer, a explicação com base nos modelos teóricos de análise de controvérsias, como aqueles apresentados por Clarke (1990) e Nelkin (1975), esbarra diante da constatação de que os expertos estão ignorando o que determinado campo científico tem dito sobre determinado assunto e tomando a questão como problemática (apenas) de suas disciplinas para justificarem seus posicionamentos políticoepistemológico (GIERYN, 1983).

Ou seja, o processo de definição de fronteiras, como forma de se legitimar enquanto produtora de conhecimento científico sobre determinado assunto, e que passa pela separação entre ciência e ideologia, ou ciência e religião, tal como propôs Gieryn (1983), como forma também de angariar prestígio no interior de um determinado campo científico, é nublado na experiência aqui descrita, ao nos depararmos com processos onde ciência e ideologia, menos que andarem de forma separada, são antes mobilizadas conjuntamente para reforçarem os argumentos apresentados pelos especialistas ouvidos na audiência da ADPF 442. No entanto, como temos mostrado até aqui, os argumentos apresentados pelos expertos estão todos, em maior ou menor grau, pautados em argumentos científicos e técnicos, no campo da saúde ou do direito, e todos envoltos em economias morais de distintas ordens. Isto é, motivações comportamentais e normativas que estão pautados em imaginários de (equidade ou não de) gênero, raça, etnia, posição política, filiação religiosa etc. Na lógica dessas economias morais, ao menos duas delas merecem especial destaque: a do gênero e a da lógica do cuidado. 


\subsection{Gênero, Cuidado e Economias Morais - Dinâmicas de Coprodução e Duplo Fazer}

Como temos mostrado, na lógica do duplo fazer e da coprodução, o gênero é produto e produz o conhecimento científico, técnico e jurídico, além da própria controvérsia aqui analisada. Quando analisamos as primeiras respostas estatais e da sociedade civil à epidemia de Zika Vírus no Brasil, pudemos notar que eram os imaginários de gênero que orientavam aquelas ações (SACRAMENTO; COSTA, 2018). No contexto aqui analisado, também são os significados de masculinidades e feminilidades que, entendidos em relação, são produzidos pelas falas dos expertos na defesa de seus pontos de vista sobre a matéria em questão. É essa mesma relação e esses mesmos significados que constroem o gênero.

Quando as representantes da ONG Anis ou do grupo Católicas Pelo Direito de Decidir afirmam que a Suprema Corte deve acatar a pauta da descriminalização do aborto a fim de garantir os direitos sexuais e reprodutivos e a cidadania plena das mulheres, elas o fazem tendo como ponto de partida a ideia (auto reclamada como feminista) de que as mulheres também são sujeito de direito e que não podem ser discriminadas por suas diferenças biológicas ou culturais em relação aos homens. Essa mesma ideia de garantia dos direitos é retomada pelas representantes do Ministério da Saúde, e de outras instituições, quando afirmam que o aborto é um problema de saúde pública e, como tal, deve ser encarado pelos formuladores de políticas públicas nos processos de governança.

Aqui, ser um problema de saúde pública não exclui a variável gênero. Ao contrário, na lógica da coprodução e do duplo fazer, e no interior do debate sobre os determinantes sociais em saúde (BARATA, 2012), o gênero, assim como classe, a raça/etnia, a geração e a localização geográfica, informam de forma substancial a gravidade do problema ${ }^{11}$. No caso do aborto, o gênero é peça central dessa retórica, ao mobilizar significados de feminilidades (mas masculinidades também) na construção do problema social e sanitário e ao construir esses (e outros) significados de feminilidades (e masculinidades) a partir dos mesmos discursos sociais e sanitários. 
Quer dizer, mobiliza-se o gênero para construir os argumentos favoráveis ao acolhimento da pauta da ADPF 442 com vistas a tornar pleno os direitos sexuais e reprodutivos das mulheres e plena também o exercício de cidadania dessas, mas mobiliza-se o mesmo gênero (e suas relações) nos discursos que argumentam que a descriminalização só acarretaria maiores problemas à saúde pública e às próprias mulheres, agora numa lógica de proteção e cuidado. Esse cuidado, no entanto, opera numa lógica polissêmica que, aliado à lógica da proteção, é capaz de ser manejado pelos dois lados da controvérsia.

Os que defendem a descriminalização do aborto alegando o pleno direito das mulheres afirmam ser obrigação do Estado a resolução desse problema social e de saúde pública com vistas a cuidar e garantir a integridade da saúde das mulheres. Aqueles que se manifestam contrários à descriminalização manejam a retórica do cuidado como meio de proteger a vida do feto e a necessidade de garantia de outras políticas públicas de cuidado às mulheres que poderiam querer recorrer ao aborto (ainda que em casos de gravidez de risco ou aquela oriunda de violência sexual).

Mesmo aqueles que, como bem mostrou a socióloga Maria José do Rosado Nunes, estariam orientados por seus preceitos religiosos e que mobilizam argumentos técnicos da área jurídica para se contraporem à ação em questão, como quem quisesse se manifestar indiretamente contra a descriminalização do aborto, o fazem mobilizando gênero e cuidado. Janaína Paschoal, advogada e professora universitária, uma das especialistas ouvidas na ADPF, alegou em seu discurso sua preocupação com as possíveis alterações nos artigos 124 (aborto provado em si mesma) do Código Penal pudessem retirar o ônus daqueles que, à época, vinham sendo investigados pelo artigo 126 (provocar o aborto em alguém). Na mesma fala, a expositora alegou também, diferente dos colegas juristas que defendiam o direito à vida com base na premissa de que esta começava já na concepção, que o que estaria em jogo não era a vida (do feto), mas ( seu) o direito de nascer.

Novamente gênero e cuidado se relacionam. No argumento apresentado por Janaína as alterações na lei, ainda que pudessem beneficiar as mulheres, livrando-as da acusação do crime de aborto, 
lhes vitimizaria, ao livrar também aqueles que tivessem lhes causado um aborto. E menos que colocar em confronto direito das mulheres e direito de uma possível vida, o feto, prefere argumentar pelo direito a vida, deslocando a chave argumentativa para um direito fundamental que se quer descorporificado (sem gênero, sem sexo, sem raça, sem classe, sem geração).

\section{Conclusão}

Se a epidemia de Zika Vírus no Brasil e a microcefalia a ela associada foram o motor que impulsionou e reanimou o debate sobre o aborto na esfera pública brasileira (ao menos no que diz respeito às altas instituições como a Suprema Corte), essa epidemia foi coadjuvante na maioria dos discursos dos expertos que se pronunciaram na audiência pública da ADPF 442. No entanto, ainda que esquecida, foi essa relação causal entre uma arbovirose e uma síndrome congênita, que provoca danos ao desenvolvido do embrião e do feto (e dano também em indivíduos adultos), que fez com que controvérsias científicas viessem à tona (ou fossem reanimadas e levadas ao debate público) e que fosse constituído uma assembleia de discussão pública onde especialistas puderam se reunir para debater um processo de governança pública.

O advento da epidemia de Zika e o crescimento da taxa de nascidos com microcefalia e com Síndrome Congênita do Zika, trouxeram novamente ao debate público a necessidade de soluções que contemplassem não apenas a epidemia da febre Zika, como também, os desdobramentos dessa doença (suas síndromes). Nesse sentido, o gênero é acionado na construção dessas respostas, seja nas orientações emitidas pelo Ministério da Saúde para as gestantes, seja na própria reivindicação de maior acesso aos métodos contraceptivos e políticas de saúde sexual e reprodutivas - como no caso do aborto (SACRAMENTO; COSTA, 2018). Se, a princípio, tal estratégia foi descartada pelo Ministério mesmo em termos de discussão, ela retornaria à cena pública a partir de reivindicações de organizações e pessoas ligadas às pautas feministas e de direito à saúde e direito das mulheres, sendo que sua materialização se realizou com a ADPF 442 protocolada no Supremo Tribunal Federal no início de 2017. 
Como se mostrou durante o artigo, a controvérsia jurídica a respeito do acesso (negado) das mulheres aos direitos sexuais e reprodutivos (a interrupção voluntária da gravidez), possibilitada pela epidemia de Zika Vírus e da Síndrome Congênita do Zika, colocou em cena também outras controvérsias científicas, técnicas e morais. O questionamento sobre se a Suprema Corte teria a legitimidade institucional para tratar sobre o tema escamoteava um argumento de ordem moral-religiosa que dizia respeito as posições sociais ocupadas pelos diversos atores que se apresentavam majoritariamente como contrários à acolhida da pauta, alegando não ser aquele lugar, o STF, a instituição mais indicada para debater o tema - seja por falta de representatividade democrática ou por impossibilidade legal.

Esses mesmos argumentos de ordem moral-religiosas também estavam por trás da controvérsia que se instalou quando do debate sobre o início da vida. Mesmo para os cientistas presentes, que conhecem a dinâmica de produção de conhecimento das ciências biológicas e estão minimamente familiarizados com os debates a respeito dessa tese, a adesão a tese da Embriologia, de que a vida começaria no momento da concepção, pode ser lida menos como a vitória desse subcampo sobre os outros subcampos das ciências biológicas e mais como um recurso argumentativo para fazer valer seu ponto de vista na controvérsia em questão. Ou seja, lança-se mão da resolução (que pode ser lida como temporária) de uma controvérsia científica no âmbito das ciências biológicas para legitimar um argumento que, se considerasse a latência dessa controvérsia, não daria sustentáculo a tese sobre o início da vida.

Nessa direção, percebe-se então uma constante suspensão dos dados científicos, por parte dos próprios cientistas, colocando sob escrutínio público métodos, metodologias e as ditas "verdades" científicas que, em um contexto de discussão que não fosse considerado "polêmico", talvez nunca viesse a ser utilizada. Afinal, o dissenso em torno de determinado tópico quase nunca é objeto de publicização, preferindo os cientistas resolverem suas discordâncias de modo mais discreto. Ao se questionar a legitimidade dos dados apresentados, por exemplo, pelo Ministério da Saúde, os expertos que se apresentaram como contrários à pauta da ADPF trazem ao debate público um debate 
que, em outro momento ou se tratando de outro tema, seria feito no interior de seus próprios fóruns e publicações especializadas - como bem afirma Clarke (1990).

Nesse sentido, coloca-se em questão a própria legitimidade da pauta enquanto um problema de saúde pública, transformando-o em um problema menor no interior desse campo, ou então, em um problema politicamente localizado para um determinado grupo social posicionado num determinado espectro do comportamento político (as feministas). Ou ainda, em um não problema sanitário. Pôr em xeque a natureza desse problema tem como consequência colocar em xeque a própria serventia da audiência convocada para discuti-lo. Como quem dissesse "o problema não existe, não há por que discuti-lo".

Em maio de 2019, o Supremo Tribunal Federal deveria ter julgado a matéria em questão. Dado o clima de instabilidade política e a onda conservadora demonstrada não apenas pelos representantes governamentais, mas também pelos agentes públicos e pela própria sociedade civil, a matéria foi retirada de pauta e não há previsão para seu retorno. A votação da matéria não traria, necessariamente, a resolução às controvérsias apresentadas aqui. No máximo, mostraria aqueles que se apresentaram contrários à pauta que a Suprema Corte possui as prerrogativas de legitimidade institucional para legislar sobre o tema. Mas a embriologia e a neurociência ainda continuariam a se debater sobre o início da vida, os profissionais de saúde ainda teriam de convencer (e, alguns, serem convencidos) de que o aborto se trata sim de um problema de saúde pública, a despeito da opinião pessoal de alguns, as feministas ainda teriam de reiterar que a defesa da pauta nada tem a ver com a defesa de comportamentos eugênicos e os atores religiosos e leigos ainda se debateriam sobre o que cada religião teria a dizer sobre a questão.

No entanto, a descriminalização do aborto resolveria problemas de ordem social, política e sanitária, ao permitir que as mulheres possam decidir, livremente, sobre quando levar adiante uma gravidez, ponderar sobre as responsabilidades do cuidado de uma criança com algum tipo de deficiência, além de se configurar como mais uma das respostas à epidemia de Zika Vírus que, mesmo marcada por gênero, não estaria de antemão reproduzindo as lógicas de desigualdade generificadas. 
Talvez seguir aqui a fala da representante da Sociedade Brasileira para o Progresso da Ciência (SBPC), a biomédica Helena Nader, que afirma que o valor de uma vida é determinado por questões morais e não científicas, pode ser um caminho a ser trilhado para pensar o desfecho dessas controvérsias, já que algumas delas, quiçá, não existiriam se não se tratasse de um tema "polêmico" e "delicado", nas palavras da ministra relatora do processo ${ }^{12}$.

\section{Notas}

1 Tais controvérsias se manifestaram no início da epidemia tanto em relação à "paternidade" da descoberta da ligação entre Zika Vírus e microcefalia (DINIZ, 2016), quanto na questão de saber se outros fatores externos à epidemia também estariam ligados ao desenvolvimento da microcefalia, como no caso do uso de larvicidas, hipótese descartada pelos estudos da época (CAIRES-JÚNIOR et al., 2018).

2 Alguns autores apontam inclusive, no Brasil, relações de cooptação dos movimentos sociais por parte do Estado (DRUCK, 2006), por meio do financiamento e delegação de decisões, de forma semelhante ao que Turner $(2001 ; 2003)$ descreveu para o que ele chamou de novos experts (consultores, líderes de ONGs e movimentos sociais financiados pelo Estado), nesse aspecto, na atual democracia liberal (VICENTE, 2019).

3 Parte dos estudos de Nelkin dedicou-se à questão das controvérsias científicas, buscando entender não somente o comportamento da comunidade científica, mas também as motivações que levam agentes públicos e movimentos sociais a participar dos debates, bem como as incertezas que marcam o processo de construção do conhecimento. Entretanto, na década de 1990, Collins e Turner recuperaram a noção de expertise. Para esses, o fenômeno (expertise) não se ocupava mais de apontar os possíveis incrementos de políticas, mas sobretudo de referendar o conhecimento a partir de uma retomada da visão "positivista".

4 Tal estado mental coletivo e compartilhado pelos cientistas que fala Daston seria diferente do estilo de pensamento de uma comunidade científica proposto por Ludwick Fleck (2010 [1935]). Para o médico polonês, um estilo de pensamento seria uma coerção definida de pensamento formada pela totalidade das disposições mentais para uma determinada maneira de perceber e de agir. O fato científico, por sua vez, dependeria desse estilo de pensamento (FLECK, 2010, p. 110). Para Daston, menos que disposições mentais que exercem uma atividade coercitiva, esse estado mental coletivo e partilhado pelos cientistas seria parte integrante do próprio fazer científico e de seu produto final.

5 Pesquisa Care, health and stigma among families affected by the Congenital Zika Syndrome in Campina Grande, coordenada pela antropóloga Debora Diniz e publicada pela editora Letras Livres em 2017 sob o título Zika em Alagoas: a urgência de direitos.

6 A ADPF 442 deveria ter sido julgada em maio de 2019. No entanto, por questões não explicitadas pelo Supremo Tribunal, e devido ao clima de recrudescimento político vivido pelo país naquele momento, a ação foi retirada de pauta sem previsão de retorno. 
7 Não estivemos presentes nos dias em que foram realizadas as audiências da ADPF 442. Acompanhamos, no entanto, as notícias via portais eletrônicos, mensagens de texto e redes sociais, conforme o debate transcorria. Entretanto, como interessados em pensar as respostas brasileiras dadas à epidemia de Zika Vírus, e entendendo a ADPF 442 como uma delas, assistimos inúmeras vezes o registro integral da audiência disponibilizada pelo STF em seu canal na plataforma de vídeos YouTube. A observação sistemática das gravações nos permitiu ver e rever as falas de todos os depoentes, atentarmos para os detalhes retóricos e para as estratégias narrativas que esses utilizavam para construir os argumentos apresentados à Suprema Corte. Assim, o recurso aos registros do STF nos permitiu captar mais detalhadamente o que foi enunciado na audiência. Contudo, isso não limita a força crítica de nossa etnografia. Pelo contrário, utilizar desse recurso talvez nos tenha dado uma vantagem analítica que nos permitiu fazer uma etnografia mais "completa", do ponto de vista da integridade dos fatos analisados. Ao mesmo tempo, nos permitiu também o acesso integral a um evento público que, caso dependesse de nossa participação no plenário, poderia ser comprometida pelas formalidades exigidas para o acesso à plateia da Suprema Corte. Ademais, mesmo que comprometidos com posições que privilegiem a ampliação dos direitos sexuais e reprodutivos, numa lógica de autonomia e direitos humanos, nossa análise também está comprometida com um certo tipo (peculiar) de ciência feminista muito signatária do pensamento de Donna Haraway (1995 [1988]): a de se fazer uma ciência que, além de parcial e localizada, se mostra também responsável e capaz de ser responsabilizada. Nessa lógica, pôr em escrutínio sociológico as narrativas aqui analisadas serve também para construir conhecimentos que sejam capazes de prestar contas ao mundo onde ele está localizado.

8 As entidades representadas pelos expositores na audiência tiveram 20 minutos para apresentarem seus pontos de vista sobre a matéria em questão. Elas foram escolhidas pela Corte, como representantes da sociedade civil, a partir da inscrição prévia, com envio de um memorial defendendo suas posições, que aconteceu no primeiro semestre de 2018.

9 Ao finalizar sua fala, o senador ainda "ameaçou" que, caso a ADPF fosse acatada pela Suprema Corte, ele emendaria a lei de crimes ambientais, "para que o feto tenha o mesmo direito que um ovo de tartaruga" - já que, para o expositor, haveria uma rigidez maior na legislação para a defesa da vida de animais do que para a vida humana.

${ }^{10}$ A Sociedade Brasileira para o Progresso da Ciência foi representada também pelo geneticista Thomaz Rafael Gollop e pelo ginecologista Olímpio Moraes Filho que, com Helena Nader, apresentaram os argumentos favoráveis da SBPC ao acolhimento da pauta da descriminalização do aborto.

11 Na fala das representantes do Ministério da Saúde e de outras entidades, a negação do acesso ao aborto e as consequências do abortamento inseguro seriam maiores quando a mulher fosse das classes mais baixas e de raça negra. Aqui também é possível perceber como outras categorias de diferenciação, a classe e a raça/etnia, operam também na dinâmica do duplo fazer e da coprodução entre a saúde, as práticas de Estado e as científicas.

12 Nas palavras da ministra relatora do processo, Rosa Weber, quando da abertura dos trabalhos da ADPF “[...] trata-se de tema jurídico delicado, sensível, altamente polêmico, enquanto envolve razões de ordem ética, moral e religiosa que provoca, muitas vezes, reações extremadas $[\ldots]^{\prime \prime}$. 


\section{Referências}

BARATA, Rita Barradas. Como e por que as desigualdades sociais fazem mal à saúde. Rio de Janeiro: Fiocruz, 2012.

BERQUÓ, Elza (org.). Sexo \& vida: panorama da saúde reprodutiva no Brasil. Campinas: Unicamp, 2003.

BRASIL. Casa Civil. Dispõe sobre o processo e julgamento da arguição de descumprimento de preceito fundamental, nos termos do $\S 1^{\circ}$ do artigo 102 da Constituição Federal, 1999. Disponível em: http://www.planalto.gov. br/ccivil_03/leis/19882.htm. Acesso em: 9 set. 2019.

CAIRES-JÚNIOR, Luiz Carlos et al. Discordant congenital Zika syndrome twins show differential in vitro viral susceptibility of neural progenitor cells. Nature Communications, [S.l.], v. 9, p. 475, 2018.

CLARKE, Adele E. Controversy and the development of Reproductive Sciences. Social Problems, [S.l.], v. 37, n. 1, p. 18-37, 1990.

CORREA, Mariza. Morte em família: representações jurídicas de papéis sexuais. Rio de Janeiro: Graal, 1983.

DASTON, Lorraine. The moral economy of Science. Osiris, [S.l.], v. 10, p. 2-24, 1995. Disponível em: http://www.jstor.org/stable/301910. Acesso em: 9 set. 2019.

DINIZ, Debora. Zika: do sertão nordestino à ameaça global. Rio de Janeiro: Civilização Brasileira, 2016.

DRUCK, Graça. Os sindicatos, os movimentos sociais e o governo Lula: cooptação e resistência. Observatório Social da América Latina, Clacso, Buenos Aires, Argentina, ano VI, n. 19, jun. 2006.

FLECK, Ludwik. Gênese e desenvolvimento de um fato científico: introdução à doutrina do estilo de pensamento e do coletivo de pensamento. Belo Horizonte: Fabrefactum, 2010 [1935].

GIERE, Ronald N. Controversies involving science and technology: a theoretical perspective. In: ENGELHARDT, Hugo Tristam; CAPLAN, Arthur L. Scientific controversies: case studies in the resolution and closure of disputes in science and technology. Cambridge: Cambridge University Press, 1989. p. 125-150.

GIERYN, Thomas. Boundary-Work and the Demarcation of Science from Non-Science: Strains and Interests in Professional Ideologies of Scientists. American Sociological Review, [S.l.], v. 8, v. 6, p. 781-795, 1983.

HARAWAY, Donna. Saberes localizados: a questão da ciência para o feminismo e o privilégio da perspectiva parcial. Cadernos Pagu, Campinas, n. 5, p. 7-41, 1995 [1988]. 
JASANOFF, Sheila. Contested Boundaries in Policy-Relevant Science. Social Studies of Science, [S.l.], v. 17, n. 2, p. 195-230, 1987.

JASANOFF, Sheila. (No?) Accounting for expertise. Science and Public Policy, [S.l.], v. 30, n. 3, p. 157-162, 2003.

JASANOFF, Sheila. The idiom of co-production. In: JASANOFF, Sheila (org.). States of Knowledge: the co-production of science and social order. New York: Routledge, 2004. p. 1-12.

JASANOFF, Sheila. Future Imperfect: Science, technology, and the imaginations of modernity. In: JASANOFF, Sheila; KIM, Sang-Hyun (org.). Dreamscapes of Modernity: sociotechnical imaginaries and the fabrication of power. Chicago: University of Chicago Press, 2015. p. 1-33.

LUGONES, María Gabriela. ¿Matronato? Gestiones maternales de protección estatal. Cadernos Pagu, Campinas, n. 51, e175102, 2017. Disponível em: http://www.scielo.br/scielo.php?script=sci arttext\&pid = S0104-83332017000300303\&lng =pt\&nrm=iso. Acesso em: 9 set. 2019.

MCMULLIN, Ernan. Scientific controversy and its termination. In: ENGELHARDT, Hugo Tristam; CAPLAN, Arthur L. Scientific controversies: case studies in the resolution and closure of disputes in science and technology. Cambridge: Cambridge University Press, 1989. p. 49-92.

NELKIN, Dorothy. The Political Impact of Technical Expertise. Social Studies of Science, [S.l.], v. 5, n. 1, p. 35-54, 1975.

NELKIN, Dorothy. Controversies and the authority of science. In: ENGELHARDT, Hugo Tristam; CAPLAN, Arthur L. Scientific controversies: case studies in the resolution and closure of disputes in science and technology. Cambridge: Cambridge University Press, 1989. p. 283-294.

NOWOTNY, H. Democratising expertise and socially robust knowledge. Science and Public Policy, [S.l.], v. 30, n. 3, p. 151-156, 2003.

PSOL - PARTIDO SOCIALISMO E LIBERDADE. Arguição de

Descumprimento de Preceito Fundamental. Brasília, 6 de março de 2017.

SACRAMENTO, Jonatan; COSTA, Maria Conceição. Gênero e saúde em contexto de duplo fazer: as respostas ao Zika vírus no Brasil. Anais da $31^{\text {a }}$ RBA. Disponível em: http://www.evento.abant.org.br/rba/31RBA/ files/1541428089_ARQUIVO_SACRAMENTO_COSTA_trabalho_completo. pdf. Acesso em: 9 set. 2019. 
SHAPIN, Steven; SCHAFFER, Simon. Leviathan and the air-pump: Hobbes, Boyle and the experimental life. Princeton: Princeton University Press, 1985.

TURNER, Stephen. What Is the Problem with Experts? Social Studies of Science, [S.l.], v. 31, n. 1, p. 123-149, 2001.

TURNER, Stephen. Liberal Democracy 3.0: Civil Society in an Age of Experts. London: Sage Publications, 2003.

VIANNA, Adriana; LOWENKRON, Laura. O duplo fazer do gênero e do Estado: interconexões, materialidades e linguagens. Cadernos Pagu, Campinas, n. 51, el75101, 2017. Disponível em: https://www.scielo.br/pdf/ cpa/n51/1809-4449-cpa-18094449201700510001.pdf. Acesso em: 16 mar. 2018.

VICENTE, Alexandre Meloni. Além dos limites legais: a preocupação com as cobaias de laboratório. 2019. 255 p. Tese (Doutorado) Universidade Estadual de Campinas, Campinas, 2019.

Recebido em 09/09/2019

Aceito em 24/04/2020

\section{Jonatan Sacramento}

Mestre em Antropologia Social e doutorando em Ciências Sociais pela Unicamp. Tem interesse nas áreas de Estudos de Gênero, Antropologia da Saúde e da Ciência, estudando, principalmente, as intersecções entre gênero, ciência e saúde na conformação das experiências epidêmicas.

Endereço Profissional: PPGCS/IFCH/Unicamp, Rua Cora Coralina, n. 100, Cidade Universitária, Campinas, SP. CEP: 13083-896.

E-mail: jonatansacramento@gmail.com

\section{Maria Conceição da Costa}

Professora Titular, MS-6, pela Universidade Estadual de Campinas (UNICAMP). Livre Docente em Estudos Sociais da Ciência pela Unicamp. Doutora em Ciência Política pela Universidade de São Paulo (USP). Líder do Grupo de Pesquisa Estudos Sociais da Ciência e da Tecnologia do CNPq. Professora do Programa de Doutorado em Ciências Sociais e do Programa de Pós-Graduação em Política Científica e Tecnológica, ambos da Unicamp. Tem atuado como pesquisadora e consultora em projetos nacionais e internacionais. Socióloga e Cientista Política, trabalha com Sociologia da Ciência e Tecnologia; Políticas Públicas; Cooperação Internacional em Ciência e Tecnologia; Análise das Ciências da Vida nos BRICS; Sociologia da Saúde e Ciência e Relações de Gênero.

Endereço Profissional: Instituto de Geociências, Departamento de Política Cientifica e Tecnológica, Universidade Estadual de Campinas, Rua Carlos Gomes, n. 250, Cidade Universitária, Campinas, SP. CEP: 13083-855.

E-mail:mariacon@unicamp.br 